\title{
Traditional Colonial-type cheese from the south of Brazil: A case to support the new Brazilian laws for artisanal cheese production from raw milk
}

\author{
Michelle de Medeiros Carvalho, ${ }^{1}$ Luciana Oliveira de Fariña, ${ }^{2}$ Daniel Strongin, ${ }^{3}$ Célia Lucia L. F. Ferreira, ${ }^{4}$ \\ and Juliano De Dea Lindner ${ }^{1 *}$ \\ ${ }^{1}$ Departamento de Ciência e Tecnologia de Alimentos, Universidade Federal de Santa Catarina, 88034-001, Florianópolis, SC, Brazil \\ 2Departamento de Ciências Agrárias, Universidade Estadual do Oeste do Paraná, 85960-000, Marechal Candido Rondon, PR, Brazil \\ ${ }^{3}$ IM Organização e Planejamento Ltda, 22281-080, Rio de Janeiro, RJ, Brazil \\ ${ }^{4}$ Departamento de Ciência e Tecnologia de Alimentos, Universidade Federal de Viçosa, 36570-900, Viçosa, MG, Brazil
}

\section{ABSTRACT}

Artisanal Colonial-type cheese is made from raw milk and is the main cheese produced by rural families of the southern region of Brazil. The aim of this study was to investigate, identify problems, and propose solutions for the current situation of small family farms producing and informally selling artisanal Colonial-type cheese located in the western part of Santa Catarina State in Southern Brazil. A semistructured questionnaire was employed in 12 rural properties to analyze the mode of production. Physical-chemical and microbiological analyses of water, raw milk, and cheese were performed, and it was found that 92,50 , and $100 \%$ of the samples, respectively, were outside of the current Brazilian regulatory parameters. None of the cheesemakers involved in this study met the requirements, as established by law, for artisanal cheese production from raw milk. This study concluded that technical support and changes in public policy are needed to ensure the preservation of this artisanal cheese, considering the historical importance and cultural traditions of these local communities and the socioeconomic importance of cheesemaking to family farming. Furthermore, more research on the safety of the cheese produced from raw milk is needed as well as the development of specific microbiological standards for artisanal Brazilian cheeses. Public policies aimed at guaranteeing food safety that formalize the commercialization of these cheeses will increase food security in those communities that currently produce artisanal cheese informally.

Key words: family farm, raw milk, food safety, agricultural economic development

Received January 25, 2019.

Accepted June 10, 2019.

*Corresponding author: juliano.lindner@ufsc.br

\section{INTRODUCTION}

Traditional Brazilian artisan cheeses are made from raw milk (Carvalho et al., 2015). Brazilian legislation prohibits the commercialization of cheeses produced from raw milk unless they have been ripened for no less than $60 \mathrm{~d}$ or are proven to be safe through laboratory testing (Brazil, 1996, 2017a). According to current legislation, cheeses ripened less than $60 \mathrm{~d}$ must be manufactured from pasteurized milk to ensure the safety of the product. However, given the transient nature of scientific knowledge and current cheesemaking practices, traditional cheeses that were never designed to undergo extended ripening, such as the French Camembert, may experience increased risk for Listeria monocytogenes when ripened for $60 \mathrm{~d}$ (D'Amico et al., 2008). Similarly, traditional Brazilian cheeses, such as Serro, Canastra, Serrano, and Colonial cheeses, have been consumed for decades without being ripened for $60 \mathrm{~d}$ (Cruz and Menasche, 2014).

Although pasteurization has introduced important safety measures to products such as cheese, eliminating pathogens from raw milk, it carries some constraints due to elimination of the autochthonous microbial population responsible for the flavor component of the majority of traditional cheese manufactured with raw milk (Gobbetti et al., 2018). The species of microorganisms present in the milk and their selection in relation to the specific process of production, such as the interaction of the lactic acid bacteria consortium, the developmental kinetics, species, and biotypes involved in the characterization of different cheeses, therefore, are key determinants for the success of a quality product (De Dea Lindner et al., 2008). To compensate for the reduction of autochthonous microbiota, microbial starter cultures are added to the process, fundamentally aiding the cheese produced from pasteurized milk with the goal of inhibiting potential pathogens (De Dea Lindner, 2016). 
To avoid losing the traditional character of their product, Brazilian cheesemakers, especially family farmers, maintain cheese production with raw milk and natural microbial starters (Dores et al., 2013; Martins et al., 2015). However, due to the regulatory requirements cited above, the cheese produced by such farmers is considered illegal and cannot be made formally available to the public. Thus, these producers work informally (Wilkinson and Mior, 1999) at the risk of having their products seized by the inspecting authorities and preventing them from gaining access to important economic policies and incentive programs for family agriculture, such as the Brazilian National School Feeding Program (Programa Nacional de Alimentação Escolar; Brazil, 2009). Among the pillars of the Programa Nacional de Alimentação Escolar is the use of a variety of healthy, safe and culturally important regional foods, supporting sustainable development through the acquisition of local food produced by family farming, which contributes substantially to reducing the economic insecurity of small producers who have difficulties marketing their food through conventional supply chains (Brazil, 2009).

The Brazilian Ministry of Agriculture, Livestock and Food Supply [Ministério da Agricultura Pecuária e Abastecimento (MAPA)], which is responsible for the inspection of animal-based products, published Normative Instruction no. 30 (Brazil, 2013) with the aim of authorizing the manufacture of cheese from raw milk with a ripening period of less than $60 \mathrm{~d}$, adjusting the mandatory requirements for industrial cheese production from nonpasteurized milk (Cruz and Menasche, 2014). For a cheese to be marketed with a ripening period of less than $60 \mathrm{~d}$, certain prerequisites must be met, such as the use of raw milk of high quality originating from zoonosis-free animals (brucellosis and tuberculosis), potable and chlorinated water, and the application of good milking and manufacturing practices to achieve the microbiological standards for cheeses.

Artisanal Colonial-type cheese (CTC) is made from raw milk and is the main cheese produced by the rural families of farmers from the southern region of Brazil (Carvalho et al., 2015). According to the latest agricultural Brazilian census, artisanal cheese production in Santa Catarina State involves more than 15,200 properties with an annual production estimated in $8,210 \mathrm{t}$ (IBGE, 2017).

Outbreaks caused by various ready-to-eat foods have been reported all over the world. Foodborne illnesses linked to cheese consumption have occurred in many countries. For example, cheeses have been linked to illnesses in the United States, Switzerland, Denmark, and France since 1985 (De Buyser et al., 2001). Several microbial risk assessments related to L. monocytogenes, Staphylococcus aureus, and Escherichia coli infections, causing cheese-related foodborne illnesses, have been conducted in different countries. However, in Brazil, to our knowledge, in part due to the lack of epidemiological data for foodborne illnesses linked to cheese consumption, no risk assessment was conducted for specific production chains of cheeses produced from raw milk. For accurate quantitative microbial risk assessment, data including interventions such as technological conditions and ripening periods should be available for predictive models developed with cheese consumption amounts and intake frequencies as well as dose-response models (Choi et al., 2016).

In this context, the objective of this study was to investigate the microbiological quality of the water, raw milk, and CTC produced and sold informally by family farmers in a municipality located in the western region of Santa Catarina State. The study aimed to identify purported issues resulting from informal cheese production, to summarize the relevant knowledge, and to recommend potential solutions while providing assistance and supporting information to regulatory Brazilian agencies, contributing to solutions for the current problem of the informal production of Brazilian artisanal cheeses.

\section{MATERIALS AND METHODS}

This study was carried out in fall (May) in the municipality of Seara (CREDISEARA: credit system comprising the entirety of the cooperative partners). These partners (around 600 families) are responsible for the whole milk production in this municipality of the state of Santa Catarina, Brazil. Of these, 71 families produce and sell CTC. Only one family produces cheese with pasteurized milk and therefore has formalized their activity and was not included in the sampling. The samples were chosen randomly from among 70 families who produce CTC in the traditional manner using raw milk, resulting in a total of 12 rural properties in the study. Considering the situation of informality, and thereby, the possibility of some of the farms refusing to participate in the research (which occurred with 3 properties), the number of sample units surveyed was higher than what was statistically necessary for a representative sample.

The conditions for production of the CTC were studied using a semistructured method, which took into account how the milk was obtained, whether good manufacturing practices were employed, and the structure of these dairies. Physical-chemical and microbiological analyses were carried out on the water, milk, 
Table 1. Microbiological quality [most probable number $(\mathrm{MPN}) / 100 \mathrm{~mL}$ ] of the water on the rural properties

\begin{tabular}{|c|c|c|c|}
\hline Rural property & Water source & Total coliforms & Escherichia coli \\
\hline 1 & Artesian well & $>2,419.2$ & 21.3 \\
\hline 2 & Natural spring & $>2,419.2$ & 32.3 \\
\hline 3 & Natural spring & 224.7 & $<1.0$ (absent) \\
\hline 4 & Artesian well & 204.6 & $<1.0$ (absent) \\
\hline 5 & Natural spring & $>2,419.2$ & $<1.0$ (absent) \\
\hline 6 & Artesian well & $>2,419.2$ & 51.2 \\
\hline 7 & Artesian well & $<1.0$ (absent) & $<1.0$ (absent) \\
\hline 8 & Artesian well & $1,203.3$ & 24.6 \\
\hline 9 & Artesian well & 464.1 & $<1.0$ (absent) \\
\hline 10 & Natural spring & $>2,419.2$ & 29.9 \\
\hline 11 & Natural spring & $>2,419.2$ & 488.4 \\
\hline 12 & Natural spring & $>2,419.2$ & 307.6 \\
\hline Standard $^{1}$ & & Absent in $100 \mathrm{~mL}$ & Absent in $100 \mathrm{~mL}$ \\
\hline
\end{tabular}

${ }^{1}$ Source: Ministério da Saúde (Brazil, 2011).

and cheese. The water and raw milk were collected on 2 consecutive days in each of the properties studied. Water was collected at the cheese manufacturing site, and raw milk was collected before the beginning of cheese production directly from the vat. The cheeses were collected for analysis after the full manufacturing period, according to the time of ripening practiced by each of the cheesemakers. All samples collected were transported and maintained at $5^{\circ} \mathrm{C}$ in coolers until analysis.

The most probable number method was applied using the Colilert system (Idexx Laboratories, Westbrook, $\mathrm{ME}$ ) for presumptive enumeration and identification of coliform and E. coli (AOAC International, 2007; Brazil, 2011). The SCC and total bacterial count (TBC) were determined in the raw milk samples. The analyses were carried out in a laboratory accredited by the Brazilian Laboratory Network of Milk Quality Control (Rede Brasileira de Qualidade do Leite) using the methodologies recommended by MAPA (Brazil, 2011).

Physical-chemical and microbiological analyses of the CTC samples followed the methodologies established by Normative Instruction no. 62 of MAPA (Brazil, 2003). Fat determination was performed using the Gerber butyrometric method, and moisture was determined by the greenhouse evaporation technique. For the microbiological analyses, the following microorganisms were investigated in duplicate in the cheese samples according to the Bacteriological Analytical Manual of the US Food and Drug Administration: E. coli and coliform bacteria, S. aureus, Salmonella sp., and L. monocytogenes (BAM, 2018).

\section{RESULTS AND DISCUSSION}

The size of the surveyed properties ranged from 2.5 to 29.3 ha (average: 13.9 ha), with a milk production of
15 to $280 \mathrm{~L} / \mathrm{d}$ (average: $147.5 \mathrm{~L} / \mathrm{d}$ ), and the production of CTC utilized raw milk.

Of the analyzed water samples (Table 1), $91.7 \%$ did not comply with the current standards for total coliforms and $58.3 \%$ did not comply with the standards for E. coli; $50.0 \%$ of the water came from natural sources and $50.0 \%$ came from artesian wells. Only one sample $(8.3 \%)$ of water sourced from an artesian well was within the current standards (rural property 7 ).

Despite the evident importance of water quality, few artisanal cheese producers monitor their water supplies, which contributes to bacterial contamination in the CTC (Piana et al., 2014). Water is widely used in food processing, and its physical-chemical and microbiological characteristics directly interfere with the sanitary quality of the food produced (Roloff, 2006). According to Brazilian legislation for the production of cheese with raw milk, dairies must carry out chlorination and ensure the potability of water used in all activities involved in processing, from obtaining raw material to final production (Brazil, 2013). The high incidence of water contamination in rural properties is a common feature detected in other regions where cheese is made with raw milk (Pinto et al., 2009; Rangel et al., 2015). Although the source of the contamination was not evaluated in this study, the problem usually originates from water sources without adequate protection, inadequate material used in the water collection system that can allow for the formation of biofilms in the water reservoirs, as well as inadequate materials used in cleaning the water collection systems. These inadequacies can represent a risk factor for the health of the producers since the analyzed water samples were used both in the manufacture of the CTC and for family consumption.

The owners of the properties evaluated did not have training in water quality control to ensure potability, 
Table 2. Raw milk quality produced on the rural properties ${ }^{1}$

\begin{tabular}{|c|c|c|c|}
\hline Rural property & $\begin{array}{l}\text { Type of } \\
\text { milking }\end{array}$ & $\mathrm{TBC} / \mathrm{mL}$ & $\mathrm{SCC} / \mathrm{mL}$ \\
\hline 1 & Mechanical & 9,000 & 386,000 \\
\hline 2 & Manual & 99,000 & 853,000 \\
\hline 3 & Manual & 42,000 & 316,000 \\
\hline 4 & Mechanical & 504,000 & 269,000 \\
\hline 5 & Mechanical & 211,000 & 269,000 \\
\hline 6 & Mechanical & $1,546,000$ & 575,000 \\
\hline 7 & Mechanical & 37,000 & 416,000 \\
\hline 8 & Mechanical & $1,786,000$ & $1,084,000$ \\
\hline 9 & Mechanical & 26,000 & 149,000 \\
\hline 10 & Manual & 52,000 & 347,000 \\
\hline 11 & Mechanical & 82,000 & 838,000 \\
\hline 12 & Mechanical & 115,000 & 924,000 \\
\hline Standard (southern region of Brazil) ${ }^{2}$ & & Maximum 300,000 & Maximum 500,000 \\
\hline
\end{tabular}

nor did they perform chlorination, which could help them solve the problems encountered. Studies carried out in other Brazilian regions found between 95 and $100 \%$ of rural farms producing milk and cheese evaluated were outside of the legal microbiological parameters for water quality (Horstmann et al., 2011; Rangel et al., 2015). If all producers of CTC were trained in the standards of good manufacturing practices, the levels of contamination observed would decrease. Therefore, the authors of this study strongly recommend that training in the proper management of water supplies be introduced and implemented in all CTC production facilities.

A total of 25 and $41.7 \%$ of the raw milk samples did not comply with standards for TBC and SCC to determine the quality of milk used for the manufacturing of CTC, respectively (Table 2).

Milk suffers contamination from the time it is collected until the time of manufacturing that can vary according to the time, temperature, and mode of exposure, thereby raising the TBC. High numbers may represent hygienic failures during milking, both in the procedures and in the hygiene of the equipment, as well as inadequate storage of the milk after it has been obtained. When manufacturing raw milk, it must be processed immediately after milking or stored in appropriate and sanitized equipment under adequate refrigeration. Studies indicate that raw milk, particularly from animals with some degree of mastitis (Ribeiro et al., 2009), is the main source vectoring $S$. aureus in cheese (Andre et al., 2008). In addition to other potential pathogens such as E. coli, the teat of the animal is considered a repository of pathogens that will infect raw milk and, consequently, cheeses (Picoli et al., 2014). When these microorganisms cross the streak canal and reach the mammary glands of the animal, they can cause clinical, subclinical, or chronic mastitis. The defense cells involved in this mechanism (somatic cells) increase their concentration in milk. Somatic cells are defined as all cells found in milk, including leukocytes of sanguine origin and epithelial cells of the secretory gland epithelium (Oliveira et al., 2011). For this reason, control of mastitis with SCC monitoring in milk is an indicator of animal health (Lopes and Souza, 2012). In addition to indicating problems in the health of the animal, an increase in SCC can lead to economic losses, since the inflammatory process is related to a decrease in milk production in the affected teats and a decrease in yield in cheese production (Silva et al., 2012).

To obtain a quality milk, it is necessary for the milk producers to be able to detect any potential health problems during milking, including subclinical mastitis, and employ appropriate hygienic procedures and correct handling. As shown in Table 2, the largest TBC were those for which the milk was obtained with mechanical milking: 1.5 and 1.7 million TBC/ $\mathrm{mL}$ refer, respectively, to the production units 6 and 8 . Mechanical milking, if misused, causes damage to the teat of the animal through improper pressure as well as increased TBC in milk through inadequate cleaning and sanitation. Therefore, these producers need training to identify these possible faults promptly to avoid nonconforming results, such as those found during this study.

The CTC was produced by the studied properties starting with the addition of chymosin-based liquid coagulant (rennet) to fresh milk (in $34 \%$ of dairies) or a mixture of the milk of the previous afternoon's milking with that just obtained on the morning of the day of manufacture (in $66 \%$ of dairies). For the addition of the rennet, the milk was preheated indirectly using a container in contact with a flame on a wood burning or gas 
stove, or without any heating (in $16 \%$ of dairies). The temperature at coagulation is not measured by the producers and may constitute a critical point involved in the wide variation in the characteristics of the cheeses produced in the same region. After complete coagulation, which lasts between 30 and 60 min, cutting of the curd is accomplished with the aid of knives or wire curd cutting tools. After cutting, the curd is stirred for 10 to 20 min until the curds are ready to be drained. In $83 \%$ of the cases, after the cut, the curds are heated to temperatures not exceeding $40^{\circ} \mathrm{C}$ and are maintained at this temperature for between 1 and $10 \mathrm{~min}$.

The addition of salt occurs in one of 3 ways: (1) direct addition of the salt to milk (in $25 \%$ of dairies); (2) addition after the drain point has been obtained (in $25 \%$ of dairies); or (3) addition after pressing when dry (in 50\% of dairies). The cheeses are pressed with the aid of a small mechanical press (in 58\% of dairies) or manually (42\%). After pressing and salting, in some cases, the cheeses are submitted to a ripening process at ambient temperature (in 50\% of dairies), under refrigeration (in $25 \%$ of dairies), or both (in $25 \%$ of dairies). This stage is also a critical point in determining the specific legislation for CTC, since each of the conditions of ripening result in cheeses with different physical-chemical, microbiological, and sensorial characteristics. Thus, based on curd treatment, the CTC produced in this region can be classified as semicooked or uncooked paste (Brazil, 1996).

The mean fat concentration (\%; Table 3) ranged from $16.00(\mathrm{SD} \pm 1.73)$ to $31.17(\mathrm{SD} \pm 1.26)$, resulting in these cheeses being classified, in relation to the fat content, into 3 categories: (1) semifat (58.4\%), (2) fat $(33.3 \%)$, and (3) extra fat $(8.3 \%)$. This variation is because, in some properties, the cream is produced from the afternoon milk by skimming the surface fat off the top, and then, the partially skim milk is held under refrigeration until the following day. This skim milk is then added to the morning milk of the following morning and used in the production of the CTC. In addition to the variation in the raw material from mixing whole morning milk with skim milk from the afternoon before, the breed and feeding practices of the animal are also critical points in the fat content of the CTC of that region.

Another important variable in cheese is the moisture (\%), which ranged from $33.88(\mathrm{SD} \pm 1.15)$ to 47.19 (SD \pm 2.03 ) in the samples. According to the current Brazilian legislation, the samples in the present study were classified as (1) low, (2) average, or (3) high moisture. All samples in the present study were classified as high moisture. The variations of moisture content identified in the samples may be related to the different modes of cheese production. High moisture content in cheeses at the end of a relatively prolonged ripening may be associated with the high relative humidity of the existing environment in the winter season in the region studied. In periods of lower relative humidity and in other periods of the year, the moisture contents obtained at the end of ripening would likely be lower, for example, after 30 d. Large variations in the composition of the CTC, both moisture and fat content were also observed by Oliveira et al. (2012), Silveira et al. (2012), and Silva et al. (2015).

Microbiological parameters were evaluated according to the moisture content (Brazil, 1996). For total coliforms, only one sample (8\%) was within the standards; however, according to the legislation of the National Sanitary Surveillance Agency (Agência Nacional de Vigilância Sanitária) responsible for the inspection of animal products at the point of sale, there are no parameters for total coliforms. These cheeses, therefore, are all eligible for sale in this respect. The specific bacteria counted among the total coliforms belonged to the genera Escherichia, Enterobacter, Citrobacter, and Klebsiella. Of these, only E. coli has the intestinal tract of humans and other warm-blooded animals as its primary habitat. Other species, such as Citrobacter, Enterobacter, and Klebsiella, in addition to being found in human and animal feces, are also present in other environments, such as plants and soil. Consequently, the presence of total coliforms in the food does not necessarily indicate fecal contamination or the occurrence of enteropathogens, probably explaining why the Agência Nacional de Vigilância Sanitária does not use total coliform levels as a microbiological parameter (Franco and Landgraf, 2008).

As for thermotolerant coliforms, 4 samples (33.3\%) were within the standards, and for coagulase-positive staphylococci, no sample was present within the standards. These 2 microorganisms were responsible for the samples testing outside of the legal parameters. It is worth highlighting data from producer number 7 . The water, milk, and cheese from this producer were within the standards, except for $S$. aureus in the cheese where the numbers $\left(5.6 \times 10^{3} \mathrm{cfu} / \mathrm{g}\right)$ were close to the standard (lower than $1.0 \times 10^{3} \mathrm{cfu} / \mathrm{g}$ ), which demonstrates the importance of these controls to obtain a quality cheese. This discussion could go further when we consider that the current standards are those used for cheese produced with pasteurized milk. When using the European Union standards for cheese made with raw milk, the cheese from producer number 7 would be fit for consumption, as well as producers $2,4,5,8,10$, and 11 (European Union, 2005).

The bacteria belonging to the thermotolerant coliforms, also called fecal coliforms by the current legislation (Brazil, 2001), which correspond to the total coli- 


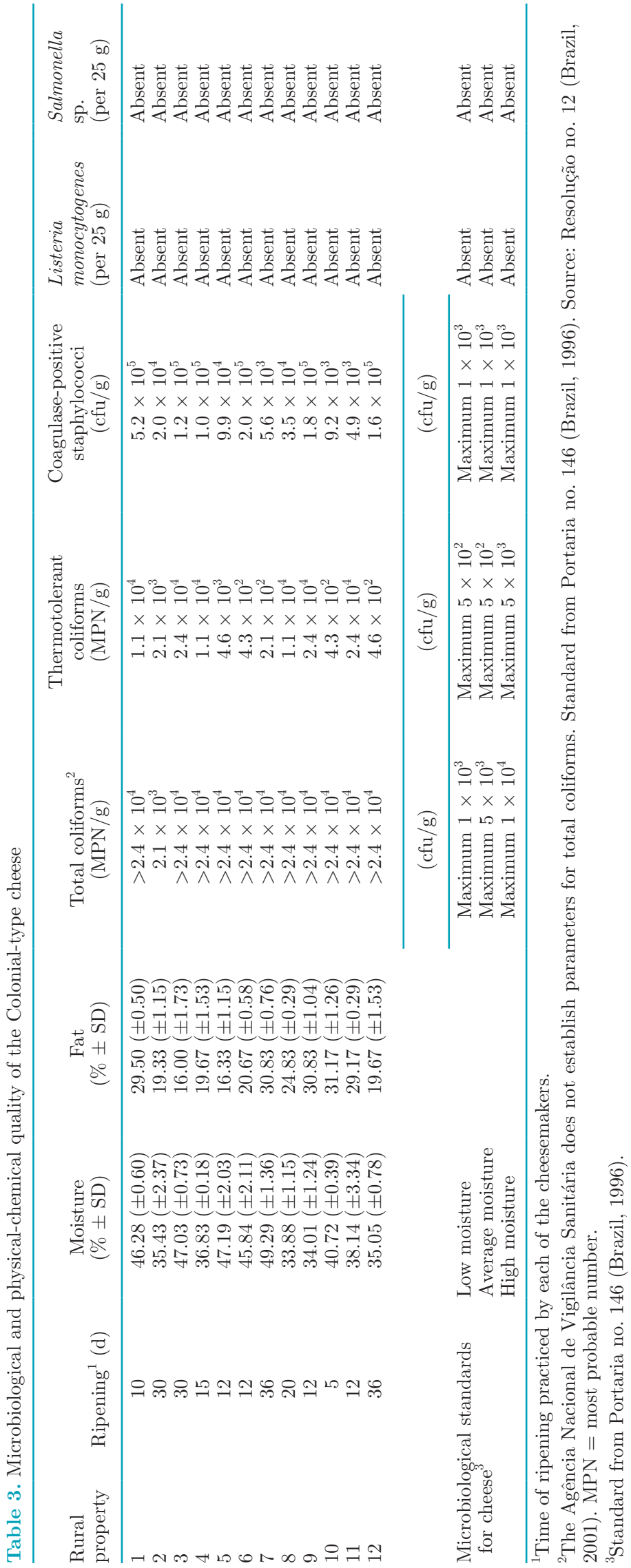


forms, have the capacity to continue fermenting lactose and produce $\mathrm{CO}_{2}$ when incubated at the temperature of 44 to $45^{\circ} \mathrm{C}$. In these conditions, approximately $90 \%$ of the bacteria present are E. coli, whereas among the other genera, only some strains of Enterobacter and Klebsiella present this characteristic (Franco and Landgraf, 2008). These microorganisms are used as indicators of hygienic-sanitary conditions applied in industrial manufacturing processes; however, in cheese made from raw milk, these microorganisms may be present in the raw material, demonstrating a need to better understand the current regulatory standards and whether they are relevant to the production of artisanal cheese from raw milk (D'Amico and Donnelly, 2010).

There are different species of the genus Staphylococcus, but the coagulase-positive biotypes of $S$. aureus are the most important because they are frequently associated with staphylococcal contamination in food. Because of this, testing for staphylococcal toxins would be a more effective way to judge whether an artisanal cheese is suitable for consumption rather than counting these microorganisms: the toxin is not produced in the food under all environmental conditions. Although $S$. aureus counts are above those permitted by current legislation, the count tends to decrease with ripening and does not rise, as it does in industrial products. This could safely allow for the elimination of the current safety margin in the regulatory standards, which are kept low to compensate for the tendency of counts to rise in industrially produced pasteurized products. The current standard jeopardizes the ability of CTC to earn the classification "within the standards" (Dores et al., 2013; Hunt et al., 2015; Martins et al., 2015).

Discussion of the standards required for artisanal products, because of the origin of the raw material and the type of processing employed, led the US Food and Drug Administration and the European Union to stop monitoring nontoxigenic $E$. coli in cheeses made with raw milk so as not to impede the production of these foods due to the rigor of industrial and international standards. In accordance with the World Trade Organization, US public health standards must be based on sound scientific evidence (Trmčić et al., 2016). The Scientific Committee on Veterinary Measures relating to Public Health issued an opinion in 1999 on the evaluation of microbiological criteria for food products of animal origin for human consumption. It highlighted the relevance of basing microbiological criteria on formal risk assessment and internationally approved principles. The opinion recommends that microbiological criteria should be relevant and effective in relation to consumer health protection.

The microbiological criteria for foodstuffs adopted by the European Union (2005) states that, for cheeses made from raw milk, coagulase-positive staphylococci may not exceed $10^{5} \mathrm{cfu} / \mathrm{g}(M)$ during the manufacturing process when the number of staphylococci is expected to be highest. In the case of unsatisfactory results, the cheese batch has to be tested for staphylococcal enterotoxins, and improvements in production hygiene and selection of raw materials need to be implemented. The microbiological limit applied in the European Union is $10^{2} \mathrm{cfu} / \mathrm{g}$ higher than that applied in Brazil. The European value is reasonable considering that, for cheeses made from raw milk, the microbiological count tends to decrease with ripening, thus a safety parameter as high as the Brazilian standard is not required. Using the European Union criterion, $58,3 \%$ of the samples from this study would meet the standards without any intervention in the process being deemed necessary.

Contamination above the current Brazilian limits for both thermotolerant coliforms and $S$. aureus (Table 3 ) may be associated with the quality of the raw material, as well as its incorrect handling and packaging, which, from the initial TBC, allowed the proliferation of these quantified microorganisms in the cheese. However, it cannot be disregarded that the CTC is produced from a raw material that has not undergone heat treatment. This means that using industrial parameters of products made with pasteurized milk as hygienic indicators for an artisanal product made with raw milk is not adequate, making it necessary to have a specific parameter for this type of product. A fair parameter, one that guarantees the safety of these handmade foods while allowing the producers the opportunity to commercialize their product and sustain themselves economically, should be implemented.

All the samples tested were within the standards for L. monocytogenes, a result equivalent to that presented in other studies of cheese produced with raw milk (Dores et al., 2013; Martins et al., 2015). The complex matrix composed of diverse microbes and unfavorable $\mathrm{pH}$ found in CTC potentially inhibited the development of L. monocytogenes. The autochthonous microbiota from raw milk may naturally inhibit the proliferation of pathogenic microorganisms during the cheese-making process (Millet et al., 2006; Aragon-Alegro, 2007). The cheeses evaluated in this study also met the standards for Salmonella sp.

Because the production is located more specifically in the western region of Santa Catarina, the CTC was exposed to large fluctuations in temperature throughout the year, which hinders the ability to standardize the temperature when ripening occurs in ambient temperature without the aid of temperature-controlled aging rooms. These seasonal fluctuations cause some producers to ripen their cheeses in a household refrigerator, especially in the summer, explaining why cheeses 
with a ripening period of $30 \mathrm{~d}$ may still show results outside the legal microbiological criteria (Dores et al., 2013; Martins et al., 2015). This situation reinforces the idea that the best way to achieve legal standards and ensure the safety of the product is the adoption of good handling, milking, and manufacturing practices. In some cases, the use of aging rooms with controlled temperatures and humidity could be advisable, but the use of climate-controlled environments will incur costs for artisanal production, requiring public aid for family farming.

The properties sampled were not certified or controlled as free from brucellosis and tuberculosis as required by legislation for the production of cheese with raw milk (Brazil, 2013). The primary reasons given by the producers were (1) lack of adequate assistance for monitoring animal health, (2) high costs, and (3) lack of government support for the certification of the herd. The lack of control of zoonosis in the herds compromises the production of cheese from the raw milk, since it is essential that the animals be proven free of these pathogens to avoid risking transmission to the consumer. Faria et al. (2014) demonstrated the presence of the etiological agent of tuberculosis in artisanal Coalho-type cheese produced from raw milk and marketed in northeast Brazil. Recently, the Brazilian National Program for the Control and Eradication of Animal Brucellosis and Tuberculosis, instituted in 2001 by the MAPA, revised the technical regulation and published Normative Instruction no. 10 in 2017 that aims to reduce the prevalence and incidence of these diseases in cattle (Brazil, 2017b). The action strategy of the Brazilian National Program for the Control and Eradication of Animal Brucellosis and Tuberculosis is based on the classification of the federative units as to the degree of risk for these diseases and on the definition and application of animal health defense procedures, according to the classification of risk. To mitigate the huge challenge for the program to certify herds in a continental country such as Brazil, zoonosis control could be decentralized to the municipality level.

\section{CONCLUSIONS}

We demonstrated in this study that the production of CTC is not capable of meeting the existing legal microbiological parameters. However, that may not prove that the cheeses studied are unfit for human consumption. A more comprehensive analysis is needed, as the microbiological parameters currently used were developed to evaluate products processed industrially from pasteurized milk. Microbiological standards specific to artisan cheese made from raw milk are urgently needed. These new regulatory standards need to take into account how the manufacturing method differs for raw material that carries an inherent microbiological load and take into account how the risks linked to the health of the herd are managed to determine whether the product is suitable for human consumption. The ban on the production and marketing of these noncompliant products is not the appropriate way to solve the problem. Risk analysis studies should be performed to better understand the true sanitary risks. The development of specific policies to support these rural producers would be of fundamental importance, not through punitive oversight, but through concrete corrective actions leading to real improvement in the health of the herd and the quality of water, milk, and cheese. Examples of concrete actions that would assist in the evolution and improvement of CTC production would be (1) the creation of programs, decentralized from MAPA, to monitor and certify properties as zoonosis free; (2) the protection of water sources in rural properties linked to improving the quality control of the water obtained from those sources; the implementation of training for the application of good handling, milking, and manufacturing practices; (3) constant monitoring of the quality of the milk and cheeses produced; (4) and the need to evaluate the microbiological risks involved in the chain of production of traditional raw milk artisan cheeses such as CTC.

\section{ACKNOWLEDGMENTS}

This study was financed in part by the Coordenação de Aperfeiçoamento de Pessoal de Nível Superior - Brasil (CAPES) - Finance Code 001. The authors are grateful to the Empresa de Pesquisa Agropecuária e Extensão Rural de Santa Catarina (EPAGRI/SC) in the municipalities of Chapecó and Seara and to the Cooperativa de Crédito Rural Seara (CREDISEARA) for generous assistance and support during the study.

\section{REFERENCES}

Andre, M. C. D. P. B., M. R. H. Campos, L. J. Borges, A. Kipnis, F. C. Pimenta, and A. B. Serafini. 2008. Comparison of Staphylococcus aureus isolates from food handlers, raw bovine milk and Minas Frescal cheese by antibiogram and pulsed-field gel electrophoresis following SmaI digestion. Food Control 19:200-207.

AOAC International. 2007. Method 991.15: Total coliforms and Escherichia coli in water. In Official Methods of Analysis of AOAC International - 18th ed. AOAC International, Rockville, MD.

Aragon-Alegro, L. C. 2007. Influência dos Coliformes no Comportamento de Listeria monocytogenes em Queijo Minas Frescal. $93 \mathrm{f}$. Tese (Doutorado em Ciência dos Alimentos) - Universidade de São Paulo.

BAM (Bacteriological Analytical Manual). 2018. Accessed in May 22, 2018. https://www.fda.gov/Food/FoodScienceResearch/ LaboratoryMethods/ucm2006949.htm. 
Brazil. 1996. Ministério da Agricultura, Pecuária e Abastecimento MAPA. Portaria 146 de 07 de março de 1996. Diário Oficial da União, Brasília, DF, 11 de março de 1996.

Brazil. 2001. Agência Nacional de Vigilância Sanitária - ANVISA. Aprova o Regulamento Técnico Sobre Padrões Microbiológicos para Alimentos. Diário Oficial da União, Brasília, DF, 10 de janeiro de 2001.

Brazil. 2003. Ministério da Agricultura, Pecuária e Abastecimento MAPA. Instrução Normativa $\mathrm{n}^{0} 62$ de 26 de agosto de 2003. Oficializa os Métodos Analíticos Oficiais para Análises Microbiológicas para Controle de Produtos de Origem Animal e Água. Diário Oficial da União, Brasília, DF, 18 de setembro de 2003.

Brazil. 2009. Lei $n^{0}$ 11.947, de 16 de junho de 2009. Dispõe sobre o atendimento da alimentação escolar e do Programa Dinheiro Direto na Escola aos alunos da educação básica. Diário Oficial da União, Brasília, DF, 17 de junho de 2009.

Brazil. 2011. Ministério da Saúde. Portaria nº 2914 de 12 de dezembro de 2011. Dispõe sobre os procedimentos de controle e de vigilância da qualidade da água para consumo humano e seu padrão de potabilidade. Diário Oficial da União, Brasília, DF, 13 de dezembro de 2011.

Brazil. 2013. Ministério da Agricultura, Pecuária e Abastecimento MAPA. Instrução Normativa $\mathrm{n}^{\circ} 30$ de 7 de agosto de 2013. 2013. Estabelece critérios adicionais para elaboração de Queijos Artesanais. Diário Oficial da União, Brasília, DF, 8 de agosto de 2013.

Brazil. 2017a. Ministério da Agricultura, Pecuária e Abastecimento MAPA. Decreto $\mathrm{n}^{0}$ 9.013, de 29 de março de 2017. Regulamenta a Lei $\mathrm{n}^{\mathrm{O}} 1.283$, de 18 de dezembro de 1950 , e a Lei $\mathrm{n}^{\mathrm{O}} 7.889$, de 23 de novembro de 1989, que dispõem sobre a inspeção industrial e sanitária de produtos de origem animal. Diário Oficial da União, Brasília, DF, 30 de março de 2017.

Brazil. 2017b. Ministério da Agricultura, Pecuária e Abastecimento MAPA. Instrução Normativa SDA n ${ }^{\circ} 10$ de 3 de março de 2017. Estabelece o Regulamento Técnico do Programa Nacional de Controle e Erradicação da Brucelose e da Tuberculose Animal PNCEBT e a Classificação das Unidades da Federação de acordo com o grau de risco para as doenças brucelose e tuberculose, assim como a definição de procedimentos de defesa sanitária animal a serem adotados de acordo com a classificação. Diário Oficial da União, Brasília, DF, 20 de junho de 2017.

Brazil. 2018. Ministério da Agricultura, Pecuária e Abastecimento MAPA. 2018. Instrução Normativa $n^{0} 31$ de 29 de junho de 2018. Altera a tabela 2 do item 3.1.3.1, do Anexo II da Instrução Normativa $\mathrm{n}^{2}$. 62, de 29 de dezembro de 2011, que aprova o Regulamento Técnico de Produção, Identidade e Qualidade do Leite tipo A, o Regulamento Técnico de Identidade e Qualidade de Leite Cru Refrigerado, o Regulamento Técnico de Identidade e Qualidade de Leite Pasteurizado e o Regulamento Técnico da Coleta de Leite Cru Refrigerado e seu Transporte a Granel. Diário Oficial da União, Brasília, DF, 30 de junho de 2018.

Carvalho, M. M., J. De Dea Lindner, and L. O. Fariña. 2015. A produção de queijo colonial artesanal no município de Seara, estado de Santa Catarina, frente à legislação brasileira. Rev. Inst. Laticínios Cândido Tostes 70. https://doi.org/10.14295/2238-6416 .v70i5.463.

Choi, K. H., H. Lee, S. Lee, S. Kim, and Y. Yoon. 2016. Cheese microbial risk assessments - A review. Asian-australas. J. Anim. Sci. 29:307-314.

Cruz, F. T., and R. Menasche. 2014. Tradition and diversity jeopardised by food safety regulations? The Serrano cheese case, Campos de Cima da Serra region, Brazil. Food Policy 45:116-124.

D'Amico, D. J., and C. W. Donnelly. 2010. Microbiological quality of raw milk used for small-scale artisan cheese production in Vermont: Effect of farm characteristics and practices. J. Dairy Sci. 93:134-147.

D'Amico, D. J., M. J. Druart, and C. W. Donnelly. 2008. 60-day aging requirement does not ensure safety of surface-mold-ripened soft cheeses manufactured from raw or pasteurized milk when Listeria monocytogenes is introduced as a postprocessing contaminant. J. Food Prot. 71:1563-1571.
De Buyser, M. L., B. Dufour, M. Maire, and V. Lafarge. 2001. Implication of milk and milk products in food-borne diseases in France and in different industrialized countries. Int. J. Food Microbiol. $67: 1-17$.

De Dea Lindner, J. 2016. Characteristics and production of microbial cultures. Pages 267-294 in Fermented Foods of Latin America: From Traditional Knowledge to Innovative Applications. 1st ed. Vol. 1. Ana Lucia Barretto Penna, Luis A. Nero, and Svetoslav D. Todorov, ed. CRC Press, Taylor \& Francis Group, Boca Raton, FL.

De Dea Lindner, J., V. Bernini, A. De Lorentiis, A. Pecorari, E. Neviani, and M. Gatti. 2008. Parmigiano Reggiano cheese: Evolution of cultivable and total lactic microflora and peptidase activities during manufacture and ripening. Dairy Sci. Technol. 88:511-523.

Dores, M. T., J. E. Nobrega, and C. L. L. F. Ferreira. 2013. Room temperature aging to guarantee microbiological safety of Brazilian artisan Canastra cheese. Food Sci. Technol. (Campinas) 33:180-185.

European Union. 2005. Commission Regulation (EC) N ${ }^{0}$ 2073/2005 of 15 November 2005 on microbiological criteria for foodstuffs. Official Journal of the European Union. L 338/26.

Faria, A. C., D. G. Schwarz, I. A. Carvalho, B. B. Rocha, C. K. N. Castro, M. R. Silva, and M. A. Moreira. 2014. Short communication: viable Mycobacterium avium subspecies para tuberculosis in retail artisanal Coalho cheese from Northeastern Brazil. J. Dairy Sci. 97:4111-4114.

Franco, B. G. M., and M. Landgraf. 2008. Microbiologia dos alimentos. Atheneu, São Paulo, Brazil.

Gobbetti, M., E. Neviani, and P. Fox. 2018. The main characteristics of the Italian cheeses. Pages 61-88 in The Cheeses of Italy: Science and Technology. Vol. 1. 1st ed. Marco Gobbetti, Erasmo Neviani, and Patrick Fox, ed. Springer.

Horstmann, J., C. A. V. L. Rosa, A. T. Neto, L. C. A. Picini, J. J. Fuck, and G. Marin. 2011. Qualidade da água utilizada na ordenha de propriedades leiteiras do Meio Oeste Catarinense, Brasil. Rev. Ciênc. Agrovet. 10:9-15.

Hunt, K., F. Butler, and K. Jordan. 2015. Modelling production of $S$. aureus enterotoxin Cbovine in milk, and its production during cheesemaking. Dairy Sci. Technol. 95:747-757.

IBGE - Instituto Brasileiro de Geografia e Estatística. 2017. Censo Agropecuário Brasileiro.

Lopes, J. E. F., and G. N. Souza. 2012. Contagem de Células Somáticas e Liberação de Bactérias de Quartos Mamários de Vacas com Mastites Subclínicas. Rev. Inst. Laticínios Cândido Tostes 67:73.

Martins, J. M., E. Galinari, N. J. Pimentel-Filho, J. I. Ribeiro Jr. M. M. Furtado, and C. L. L. F. Ferreira. 2015. Determining the minimum ripening time of artisanal Minas cheese, a traditional Brazilian cheese. Braz. J. Microbiol. 46:219-230.

Millet, L., M. Saubusse, R. Didienne, L. Tessier, and M. C. Montel. 2006. Control of Listeria monocytogenes in raw-milk cheeses. Int. J. Food Microbiol. 108:105-114.

Oliveira, C. M. C., M. G. S. Sousa, N. S. Silva, C. L. Mendonça, J. A. S. Silveira, R. P. Oaigen, and J. T. Andrade. 2011. Prevalência e etiologia da mastite bovina leiteira de Rondon do Pará. Pesqui. Vet. Bras. 31:104-110.

Oliveira, D. F., C. E. C. Bravo, and I. B. Tonial. 2012. Sazonalidade como fator interferente na composição físico-química e avaliação microbiológica de queijos coloniais. Arq. Bras. Med. Vet. Zootec. 64:521-523.

Piana, S. C., S. C. Piana, L. O. Fariña, F. A. Falconi, and J. Busarello. 2014. Avaliação da qualidade microbiológica da água de propriedades leiteiras dos municípios de Campo Bonito, Cascavel e Guaraniaçú - PR. Semin. Cienc. Biol. Saude 35:25-34.

Picoli, T., J. L. Zani, F. S. Bandeira, V. F. B. Roll, M. E. R. Ribeiro, G. A. Vargas, S. O. Hübner, M. Lima, M. C. A. Meireles, and G. Fischer. 2014. Manejo de ordenha como fator de risco na ocorrência de microorganismo em leite cru. Semin. Cienc. Agrar. 35(suplemento):2471-2480.

Pinto, M. S., C. L. L. F. Ferreira, J. M. Martins, V. A. M. Teodoro, A C. S. Pires, L. B. A. Fontes, and P. I. R. Vargas. 2009. Segurança alimentar do queijo Minas Artesanal do Serro, Minas Gerais, em 
função da adoção de boas práticas de fabricação. Pesqui. Agropecu. Trop. 39:342-347.

Rangel, A. H. N., R. M. B. Freire, L. H. F. Borba, D. M. Lima Jr., and L. P. Novaes. 2015. Qualidade microbiológica da água utilizada em propriedades leiteiras. Rev. Inst. Laticínios Cândido Tostes 70:9-16.

Ribeiro, M. G., J. S. Geraldo, H. Langoni, J. H. B. Lara, A. K. Siqueira, T. Salerno, and M. C. Fernandes. 2009. Microorganismos patogênicos, celularidade e resíduos de antimicrobianos no leite bovino produzido no sistema orgânico. Pesqui. Vet. Bras. 29:52-58.

Roloff, T. A. 2006. Efeitos da não aplicação do controle de qualidade da água nas indústrias alimentícias. SaBios: Rev. Saúde e Biologia, v. 1, n. 1 .

Silva, F., G. Silva, I. B. Tonial, and F. P. Castro-Cislaghi. 2015. Qualidade microbiológica e físico-química de queijos Coloniais com e sem inspeção, comercializados no Sudoeste do Paraná. B. Ceppa, V. 33, n. 2.
Silva, N. M. A., L. P. F. Bastos, D. L. S. Oliveira, M. C. P. P. Oliveira and L. M. Fonseca. 2012. Influence of somatic cell count and total bacterial counts of raw milk in cheese yield using small-scale methodology. Arq. Bras. Med. Vet. Zootec. 64. https://doi.org/10 .1590/S0102-09352012000500038.

Silveira, J. F. Jr., D. F. Oliveira, F. Braghini, E. M. S. Loss, C. E. C. Bravo, and I. B. Tonial. 2012. Caracterização físico-química de queijos coloniais produzidos em diferentes épocas do ano. Rev. Inst. Laticínios Cândido Tostes 67:67-80.

Trmčić, A., K. Chauhan, D. J. Kent, R. D. Ralyea, N. H. Martin, K. J. Boor, and M. Wiedmann. 2016. Coliform detection in cheese is associated with specific cheese characteristics, but no association was found with pathogen detection. J. Dairy Sci. 99:6105-6120.

Wilkinson, J., and L. C. Mior. 1999. Setor informal, produção familiar e pequena agroindústria: Interfaces. Estud. Soc. Agric. 13:29-45. 